\title{
Media Development Needs in Learning Da'wah Rhetoric in Islamic Universities
}

\author{
${ }^{1}$ Umi Faizah, ${ }^{2}$ Sarwiji Suwandi, ${ }^{3}$ Andayani, ${ }^{4}$ Ani Rahmawati \\ umifaizah84@gmail.com \\ 1,2,3,4 Universitas Sebelas Maret Surakarta
}

\begin{abstract}
Interactive audio visual media as a media for rhetorical learning of da'wah to improve speaking competence is needed by Islamic Universities. The lack of interactive audio visual learning media in learning reduces the creativity of rhetoric. Media that still dominates include puppets, puppets, cards, puzzles, recordings from cellphones and laptops. The learning approach has not been integrated with the media so that it becomes a lack of attractiveness of students to enrich ideas, ideas, creativity and imagination when doing rhetoric. The purpose of this research is to uncover the needs of learning media to increase the competence of da'wah lecturing with a scientific approach. This research uses survey method which includes observation and interviews involving 4 Islamic universities in Central Java and Yogyakarta Special Region. The results showed that students considered that interactive audio visual media in the learning of interesting da'wah rhetoric on the grounds that they would add a reference when making rhetoric. The lecturers also gave a positive appreciation for the analysis of media needs that are integrated with the learning approach. Students and lecturers need da'wah rhetoric learning media based on a scientific approach in rhetoric courses to improve speaking competence.
\end{abstract}

Keyword: Media Development Needs, Learning Da'wah Rhetoric, Islamic Universities

\section{Introduction}

Millennial society is close to the world of technology and communication. The digital learning process in the revolutionary era of Industry 4.0 is a challenge for education people. Most companies use technology to sell their products online so that Indonesia needs to improve the quality of its workforce skills with digital technology Paray[1] Technological innovations occur in all sectors. This challenge needs to be addressed with the relevance of education and work that needs to be adjusted to the development of the era and science and technology while still paying attention to humanitarian aspects.

Learning speaking courses (rhetoric) da'wah based on scientific approaches can be designed using digital media. Interactive audio visual media for students becomes a medium to stimulate student missionary activities. The design of da'wah rhetoric learning media can be used in learning directly or online for repetition of learning materials at home.

Rhetoric skills can be followed after obtaining listening skills. Students listen to the video, then retell in public with speaking activities. Throughout the history of life, humans have used public speaking as a vital means of communication Lucas[2]. Speaking skills cannot be separated from other language skills Hughes[3]. 
Da'wah as part of Indonesian society is a religious rhetoric activity (da'wah rhetoric). The many problems related to the rhetorical expertise of the political elite and the less polite society make da'wah as a guide to rhetorical activity. This is done so that it is far from the impression of sheep fighting and lies. Da'wah rhetoric is to provide fatwa by speaking to humans in the language of their time (language that is easily understood by the recipient of the fatwa, speaking rationally and not excessively, not using terms that are difficult to understand and claim the law accompanied by wisdom and illat (legal reasons) in accordance with philosophy general Islamic dynasty $\mathrm{Al}$ Quradhawi[4], In the realm of education, rhetoric is integrated with courses in Islamic Higher Education in Central Java and DIY.

Based on needs analysis and media observation in settings 1 through setting 4 there have been various learning media, but there is no media that stimulates the rhetoric of da'wah to students. Integrated learning media with learning have also not been found in supporting da'wah activities. The more skilled students are in listening to information, the more skilled they are in conveying their ideas through rhetoric. The stages begin by observing or listening to the film then telling the contents of the film the speaking activity can be a solution to convey information and ideas on the film. This is part of the scientific approach to learning. The scientific approach begins with observing, asking, exploring, associating and the last by communicating (Abdullah, 2015).

The development of da'wah rhetoric learning media based on a scientific approach to support speaking competencies needs to be designed. This is in accordance with the statements of students and lecturers who need da'wah rhetoric learning media. Media designed to be integrated with a learning approach with a scientific approach.

\section{Methodology}

The survey method was used in this study. The sampling technique was carried out by purposive sampling which was analyzed and based on the qualitative assessment of researchers. Data collection techniques are carried out by observation, interviews and questionnaires. The population was taken from students and lecturers at Muhammadiyah University in Central Java and DIY. The research settings included setting 1 at Muhammadiyah University Purworejo, setting 2 at Muhammadiyah University Purwokerto, setting 3 at Muhammadiyah University Surakarta and setting 4 at Ahmad Dahlan University.

\section{Results and Discussion}

A. Preliminary Study

1. Identify Needs

Need is a gap between hope and reality. In this case to determine the need is to collect information about the gap that should be owned by each student with what they have Sanjaya[5]. The need for learning is the gap between the abilities, skills and attitudes of students they currently have Sadiman[6].

Needs assessment is a process of gathering information or approach steps needed in program development Susanti[1], Lee along with Owens[3] argued that needs analysis is a systemic approach to determine the gap between the existing reality and something to be achieved. 
In the implementation of learning speaking courses, all settings almost carry out with the same system, namely by giving theory in advance and then carrying out the practice to support the theory and stabilization in the mastery of speaking material. Generally the material presented is in the form of speaking material which includes the notion of speaking, the purpose of speaking, the type of speech, the method of speaking and the techniques of speaking, while for practice it has varied, for example there are those who do it by telling stories, lecturing and talking politics.

From all observations in a number of Islamic Universities and interviews with lecturer informants, it was found that learning had been going on properly in a two-way system, namely lecturers giving material and students also active in learning both question and answer and practice. The clutter in learning is the absence of learning media that is integrated with the learning approach.

The use of learning media in several Islamic universities can be described as follows. In setting 1 the lecturer speaking NS said the media used as a complement to learning in the form of dolls, puzzles, luck circles, lucky pockets and pictures. It was further explained that puppets and puppets were used in storytelling and storytelling material, picture media was used for tour guide materials, Q-Cards were used for host learning and entrepreneurship. Audio visual media at all, for you tube also has not been used optimally in speaking learning (CLHW 1).

Furthermore, in the setting of $2 \mathrm{SF}$ lecturers in the course talking rhetorically with the media used is youtube. Also explained in the field notes the results of the interviews of 2 media used in the form of speaking activities of a character who has been downloaded and then analyzed both in language, and non-language by students. The media that has not been used is an interactive audio visual learning media. Based on interviews with lecturers that the media used are generally still downloading from the internet. This is due to the lack of opportunities available to make learning media collaborate with students (CLHW 2).

Unlike the setting 3 lecturers of AHP speaking courses explained that the media used were laptops and hand pones. Laptops and hand pones are used to record student speaking activities and then are appreciated to be appreciated jointly by lecturers and students in linguistic and non-linguistic terms. Based on the information from the informants at the university, there were no learning media in speaking courses that were integrated with the learning approach (CLHW 3).

The next information is the fact that occurred in setting 4 obtained by the media information used in learning is a doll or paper used to tell stories with the characters of each character. In addition, it was also explained that the media used by downloading videos of Uje characters, AA Gym, Soekarno as learning material. Learning media integrated with learning approaches have not been used at the university (CLHW 4).

The need for da'wah rhetorical learning media with a scientific approach can be seen in the questionnaire (CLHW.1, 2,3,4) which is distributed to lecturers and students reinforced by interviews. The use of instructional media that has not been integrated with IT and learning approaches is an attraction for them. In general, the results of the needs analysis with an agreed amount of $97 \%$ and who disagree $3 \%$ can be seen in the diagram below. 
Figure 1. The needs of students and lecturers for media

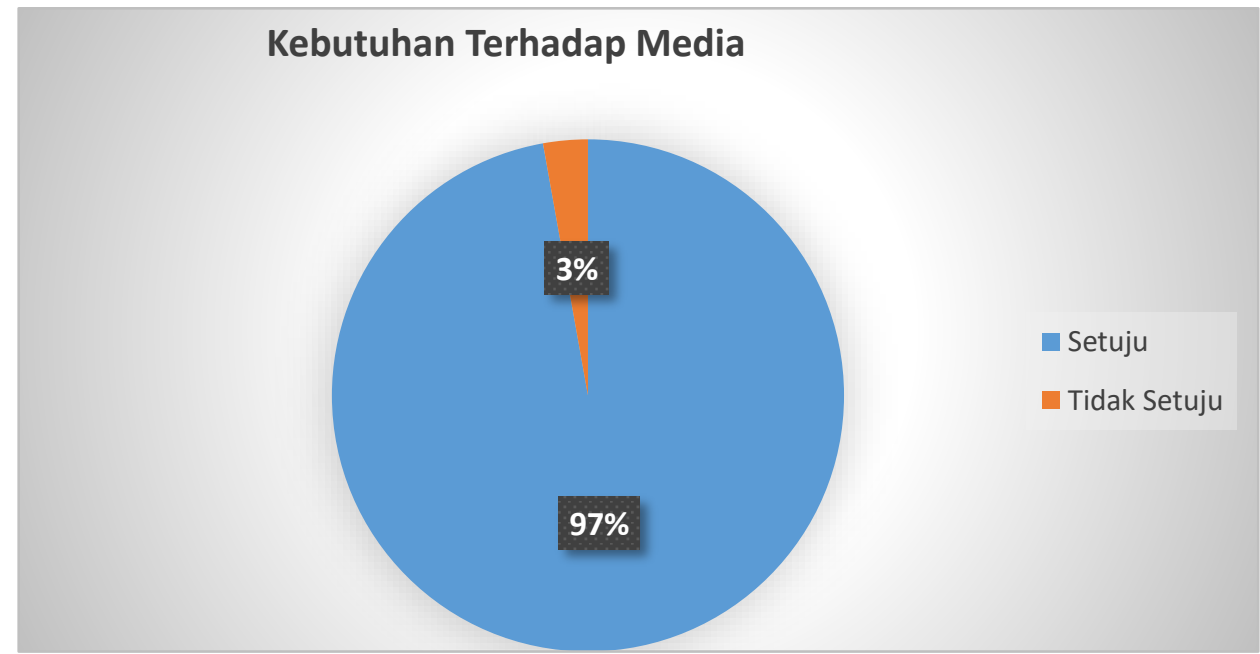

\section{a. Identification of Characteristics of Students and Lecturers}

Sources of data on media interaction needs and learning media needs are students, while data sources of learning media needs in the form of interactive audio visual media are educators of course guides.

1) Student Characteristics

a) Level of Psychological Development

Packaging materials and illustrations pay attention to the psychology of students who are happy with the challenges so that it requires precision and carefulness in choosing illustrations. Students are in the developmental stage of adulthood and tend to be independent. Lecturers in facilitating rhetorical learning require a lot of interaction from students and the media in developing learning media. With the help of the media lecturers will limit themselves not to dominate the learning process and provide sufficient time for the students of da'wah rhetoric.

b) Basic Student Ability

In general, students have been able to speak in public, but there is no KD da'wah mapping in settings 1,2 , and 3, while setting 4 has already appeared in $\mathrm{KD}$, but it has not used the media. In general, students said that it was easier when giving da'wah lectures which began with media screenings.

c) Student learning style

Students need to analyze their learning styles which include kinesthetic, audio and visual. Student learning styles are more likely to be audio and visual because their media holds that audio visual media can stimulate imagination and creative processes.

d) Student habits 
The presentation technique most favored by students is audio visual media because there is a combination of movement and music. The habit of using time will be effective if there is integration between lecturers, students and the media. Based on the needs analysis for students, information is obtained, namely the need for learning media to facilitate work 1) students place the media as valuable learning resources $(80,58 \%), 2$ ) conduct learning based on the required media $(80,62 \%)$, 3) encourage students in composing learning media $(80,50 \%), 4)$ guiding students involved in implementing the preparation of learning media $(80.26 \%)$, 5) students thinking, learning, doing and assessing activities with their learning media $(80.36 \%), 6$ ) creating a conducive learning situation between lecturers and students when using media $(80,50 \%), 7)$ developing media with technology $(80.80 \%), 8)$ involving active and responsible students in technology-based learning activities $(80.20 \%), 9)$ using a scientific approach based learning media that begins with observing, asking, exploring, associating and communicating $(80,48 \%)$.

2) Characteristics of Lecturers

In general, the age of lecturers in settings 1 to 4 ranges from 30 years - 50 years. The teaching style of lecturers varies with students as learning centers. Learning media compiled by students and lecturers have not been used in learning. The learning approach has not been used in classroom activities.

\section{b. Purpose Formulation}

The purpose of learning to speak da'wah is stated in the RPS, that is students are able to rhetorically preach in public by using good and true Indonesian. The use of media will support changes in behavior that students have. Da'wah rhetoric learning media based on a scientific approach that was compiled begins with the presentation of mini films, and then followed by steps of learning with a scientific approach which ends with the presentation of da'wah rhetoric with the themes and topics of the film in front of friends and assessed by lecturers.

\section{c. Material Development}

Based on the needs analysis of da'wah rhetoric learning media based on a scientific approach is needed to improve the competence of speaking da'wah. This media can be used both directly and in network (online) when students are at home. The material presented in the form of da'wah rhetoric material complete with the arguments of the Koran and Hadith.

\section{d. Development of Measuring Instruments}

The measuring instrument used in the interactive audio visual learning media of da'wah rhetoric based on a scientific approach is to follow the stages of learning, namely observing, asking, exploiting, associating and communicating.

Observe: students are invited to observe mini-films about social inequality, 2) ask: after students watch a movie will raise questions about the topics and themes in the film, 3) explore: look for material that matches the topics and themes found, 4) associate: develop material from the topic by connecting from the Koran, hadiths, books and the internet, 5) communicating: discussing topics that you have arranged in the presence of lecturers and friends to be assessed.

Based on the above needs analysis, the unavailability of interactive audio visual learning media in learning reduces the creativity of rhetoric. Media that still dominates include puppets, puppets, cards, puzzles, recordings from cellphones and laptops. The learning approach has not yet been integrated with the media so that it becomes a lack of attractiveness for students 
to enrich ideas, ideas, creativity and imagination while in rhetoric. Therefore, it is necessary to make da'wah rhetoric learning media based on a scientific approach.

\section{B. Media Script Planning}

After conducting a preliminary study and analyzing the needs and conditions, information was obtained that the media needed by students and lecturers were integrated media with learning. In this case the media contains forms combined with IT that can be translated with interactive audio visual media. With regard to the subject of speaking, the media needed is more about things that can add to the vocabulary which is then translated into film media. The need for an integrated approach to learning is translated with a complete scientific approach with steps.

a. Media Form

The planned media is interactive audio visual media based on a scientific approach. This video is coupled with the steps of scientific learning as a learning activity. This media is 30 minutes long in the form of soft files in flash disck and will also be available online.

b. Media Narrative

1) Synopsis

This video contains films and learning steps with a scientific approach. Synopsis: The da'wah rhetoric is the art of communicating that contains the message of da'wah addressed to the community. This video contains mini-films about social inequality which will eventually take the topic and theme of the film to be communicated in the form of da'wah rhetoric.

2) Treatment

Treatments contain steps based on scientific approaches.

Treatmen: This program begins with the student's sentence to be invited to the first stage, namely observing the following mini-films! Next came a 20-minute film about the Bidikmisi students who struggled to finish their studies in order to make their parents happy, but he had to accept the bitter truth when his mother passed away before he described his graduation! for small themes and topics. In the second stage the questioning phase comes up, please ask questions related to the mini film! The third stage explores the phrase "please search for material from the Qur'an, hadiths, books and the internet about the topic or theme chosen! The fourth stage associates the sentence appears "please connect the material with the reference obtained by completing it with the arguments of the Qur'an and hadith by making a draft in writing. The fifth stage communicates that is the rhetoric of da'wah with the Indonesian language that is good and right equipped with the arguments of the Qur'an and hadith.

\section{c. Evaluation}

The form of student evaluation after using the media is measuring the competence of da'wah rhetoric with the assessment criteria, as follows. 1) Open the da'wah rhetoric with clear and interesting sentences (maximum score of 20), 2) Organize da'wah rhetoric in harmony

(maximum score of 20), 3) Give emphasis to the most important parts with various strategies (maximum score of 20), 4) Utilizing proper expression and gestures (maximum score of 20), 5) Using time optimally 7 minutes (maximum score of 20).

\section{Conclusion}


In accordance with the analysis in the field that da'wah rhetorical learning media to support speaking competence is needed by students and lecturers. The importance of the media needs, it is necessary to plan media development which includes media forms, media narratives and evaluation tools.

\section{References}

[1] M. and S. W. Susanti, "Need Assesment of Puppet Story Audio Media Model for Teens," J. Pekomnas, vol. 2, no. 1, 2017.

[2] S. E. Lucas, The Art of Public Speaking. New York: The McGraw-Hill Companies, 2008.

[3] D. L. Lee, W. W. dan Owens, Multimedia Based Instructional Design. San Francisco: Pfeiffer, 2004.

[4] Al-Qaradawi, Fatwa-fatwa Kontemporer. Jakarta: Gema Insani, 1995.

[5] W. Sanjaya, Media Komunikasi Pembelajaran. Jakarta: Kencana, 2012.

[6] dkk Sadiman, Media Pendidikan, Pengertian, Pengembangan dan Pemanfaatannya. Jakarta: PT. Raja Grafindo Persada, 2011. 